\title{
Выборы в I Государственную Думу: опыт и уроки избирательной кампании нижегородских политических партий в 1905-1906 годах
}

\begin{abstract}
Аннотащия. Особенностью становления России как современного государства являются парламентские традииии, история которых в 2016 г. перешагнула 110-летний рубеж. Целью данной статьи является изучение опыта и уроков проведения предвыборной кампании нижегородскими политическими партиями на выборах в I Государственную Думу. В ней дана краткая характеристика ведущих политических партий Нижегородской губернии, вылвлены трудности, с которыми они столкнулись в ходе избирательной кампании, среди которых: необходимость ведения агитаиии в условиях общероссийской революиии и ограничения свободы для оппозииионных партий. Кроме того, всем партиям одновременно приходилось решать и вопросы партийного строительства, и организовывать избирательную кампанию. В ходе предвыборной борьбы использовались как конвенииональные формы и методы избирательных технологий - газетные публикачии, распространение брошюр, воззваний, листков, встречи с избирателями; так и не конвенииональные - от использования административного ресурса до махиначий с бюллетенями. Особенностью политического участия избирателей-нижегородиев в предвыборной боръбе явилось протестное поведение. В Нижнем Новгороде Конституиионно-демократическая партия одержала убедительную победу. Определенную роль в этом сыграли высокая активность агитаторов, более привлекательная для основной массы населения программа, разнообразие форм работы с электоратом, неучастие в выборах партий эсеров и соииал-демократов. Однако более глубокая причина такого исхода выборной кампании заключалась в наличии в России огромной массы протестного электората, таким способом выразивщего свое негативное отношение к политике правительства России, проголосовав за наиболее оппозичионную партию.
\end{abstract}

Ключевые слова: революиия, избирательные технологии, оппозичионная партия, Конституционно-демократическая партия, электорат, политические партии, выборы, избирательная кампания, парламент, Государственная Дума.

Abstract. A significant feature of the development of Russia into a modern state is its democratic parliamentary traditions, which in 2016 have crossed the 110-year milestone. The aim of this article is to study the experience and lessons of the election campaign of the political parties in Nizhny Novgorod during the elections to the First State Duma. The article presents a brief description of the leading political parties of the Nizhny Novgorod governorate and reveals the difficulties they faced during this election campaign, including: the necessity of conducting a propaganda campaign under the conditions of the Russian Revolution and the limited freedom of opposition parties. Additionally, all parties simultaneously had to address the issues of party formation and to organise election campaigns. During the course of the election campaign in Nizhny Novgorod, the parties used traditional forms and methods of election technologies - newspaper articles, brochures, proclamations, leaflets, meetings with voters -, as well as unconventional methods - from the use of administrative resources to manipulating ballots. A particular means of participating in the election struggle was demonstrated by the Nizhny Novgorod electorate through protest behaviour. In Nizhny Novgorod the Constitutional-Democratic Party won a landslide victory. A certain role in this victory was due to the agitators' active participation, the party's more attractive program for the majority of the population, its variety of forms in working with the electorate, and the absence in the party elections of the Socialist-Revolutionaries and the Social-Democratic parties. But the more momentous contribution to the outcome of the election campaign was due to the presence in Russia of a huge body of protest electorate, which expressed its negative attitude towards the Russian government's policy by voting for the most oppositional party.

Key words: parliament, election campaign, elections, political parties, electorate, Constitutional-Democratic Party, opposition party, election technologies, revolution, State Duma. 
История государства и права

DOI: $10.7256 / 2222-1972.2016 .2 .17899$

110 лет тому назад, 27 апреля 1906 г. в Зимнем дворце, а затем в Таврическом, начал работать первый в истории России парламент Государственная Дума. В общей сложности в первую Думу было избрано 478 депутатов. По политической принадлежности они распределились следующим образом: кадеты - 176 депутатов, октябристы - 16, беспартийные 105, трудовики - 97, социал-демократы (меньшевики) - 18. Остальные входили в состав регионально-национальных партий и объединений, в значительной части примыкавших к либеральному крылу $[1,46]$. Председателем Думы был избран кадет - С. А. Муромцев, профессор Московского университета.

После первого заседания Думы министр двора В. Б. Фредерикс поделился своими впечатлениями о народных избранниках: «Эти депутаты скорее похожи на стаю преступников, ожидающих сигнала, чтобы зарезать всех сидящих на правительственной скамье». В своем дневнике великий князь Константин Константинович написал: «Дума - очаг революции» [2, 437-438]. Несмотря на либеральный состав, I Государственная Дума с самого начала была неугодна властям и проработала всего 72 дня, одну сессию. Объяснение этому состоит в том, что представительному органу во властных российских структурах отводилась роль политической ширмы самодержавия. Не случайно все думское законодательство 1905-1906 гг. жестко ограничивало сферу ее компетенции.

На фоне общего мнения отечественных обществоведов о недостаточной демократичности избирательной системы царского правительства при выборах первого российского парламента, возникает закономерный вопрос: как все же мог сформироваться столь радикальный по составу законодательный орган России? Изучение опыта предвыборных кампаний ведущих российских партий, участвовавших в выборах в первую Думу, в определенной мере позволяет ответить на этот вопрос.

Политический спектр Нижегородской губернии, как и всей России, в годы первой русской революции был достаточно широк. Его представляли леворадикальные, либеральные и монархические организации. Однако не все они в равной степени приняли участие в предвыборной кампании в I Государственную Думу. Нижегородские әсеры отказались принимать участие в выборах. Социал-демократы также не участвовали. В своих листовках Нижегород- ский объединенный комитет РСДРП объяснял населению причины бойкота выборов: «Дума не сможет и не захочет удовлетворить требований народа... Крестьян и рабочих в нее попадет так мало, что их голос не будет слышен. Такая дума не нужна народу». Он призывал народ «объявить бойкот, не принимать никакого участия в выборах...» [3, 420]. Однако сорвать выборы левым партиям не удалось.

Основная борьба за думские места развернулась между ведущими либеральными партиями - кадетами и октябристами, хотя в избирательной кампании принимали участие и нижегородское отделение Умеренно-прогрессивной партии, и монархический союз «Белое знамя». Бойкот выборов социалистами помог кадетам получить голоса рабочих выборщиков, всех противников правительства, т. е. практически весь левый электорат. Умеренная часть нижегородского электората голосовала за представителей «Союза 17 октября», Умеренно-прогрессивной партии и союза «Белого знамени». Аналогичная ситуация была и по всей России: помимо большевиков выборы бойкотировали эсеры и правые партии.

В целом предвыборная кампания началась после опубликования нового избирательного закона от 11 декабря 1905 г. и последовавшего 20 декабря разъяснения Сената по выборам в Государственную Думу. Выборы первого российского парламента были не только не всеобщими, но и не равными и не прямыми: двухстепенными для городской и землевладельческой курий, трех- и четырёхстепенными - для избирателей из рабочей и крестьянских курий.

Ряд факторов обусловил трудности ее ведения. Прежде всего, выборы проходили в сложнейших условиях общероссийской революции. В крупных городах вновь появились на улицах вооруженные патрули, как в центре, так и на окраинах. Усилились аресты в рабочих кварталах. С целью не допустить превращения партийных собраний в грандиозные митинги, подобно октябрьским событиям 1905 г., была введена их усиленная охрана. Под пристальным контролем властей оказались и кандидатуры возможных кандидатов. По информации «Биржевых Ведомостей» при премьер-министре предполагалось формирование специальной комиссии для выяснения степени политической благонадежности кандидатов в члены Государственной Думы. Даже были намечены члены этой комиссии, но министр внутренних дел П. Н. Дурново на- 


\section{Исторический журнал: научные исследования № 2 (32) • 2016}

DOI: $10.7256 / 2222-1972.2016 .2 .17899$

шел, что учреждение такой комиссии было бы нецелесообразно, поскольку сведения о неблагонадежности кандидатов могут поставляться обычным путем [4]. Министром был разослан всем губернаторам и градоначальникам особый специальный циркуляр, в котором предлагалось весьма ограниченно пользоваться законом о предвыборных собраниях. Например, необходимо сообразовать число разрешаемых митингов с возможностью надзора за ними. Губернаторам предоставлялось право не давать разрешений во всех тех случаях, когда, по их мнению, митинг угрожал порядку и спокойствию [5].

Анализируя начало выборов в Нижегородской губернии, кадетская газета «Нижегородский листок» отмечала, что «избирательная кампания должна начаться при условиях совершенного отсутствия необходимого спокойствия в стране. Революционеры далеко еще не сложили своего оружия и не прекратили борьбы. Со своей стороны правительство не только не отказалось от применения исключительных законов по охране общественного спокойствия, но, наоборот, все более расширяет сферу и территорию их применения. При таких обстоятельствах ясно, что выборы не могут дать должного результата, не могут явиться свободным выражением народной воли. Предвыборная свободная агитация чрезвычайно затруднена. Весьма трудно будет привлечь население к участию в выборах» [6]. Все эти обстоятельства не могли не отразиться негативно на ходе предвыборной кампании.

Второй фактор, затруднявший предвыборную борьбу, заключался в том, что сами партии находились в самом начале своего становления, организационно они только оформлялись, их программы были неизвестны избирателям, у партий отсутствовал опыт ведения избирательных кампаний. Так, нижегородский комитет Конституционно-демократической партии (партии Народной свободы) был создан в ноябре 1905 г. Председателем комитета стал Г. Р. Килевейн, член губернской земской управы. Членами комитета избраны руководитель уездного земства А. А. Савельев, присяжный поверенный П. А. Рождественский, помощник присяжного поверенного В. И. Серебрянников, литератор В. Е. Чешихин-Ветринский и другие. Кадетская партия считалась ведущей в губернии, объединявшей сторонников широких социальных реформ и парламентской демократии европейского образца. Среди членов партии преобладала интеллигенция - врачи, адвокаты, служащие. В ходе предвыборной кампании, стремясь получить поддержку низших слоев общества, партия активно использовала лозунги 9-часового рабочего дня, отмены сверхурочных работ, права на забастовки и создание профсоюзов. Под контролем кадетов находилась популярная местная газета «Нижегородский листок».

Значительной силой в губернии был нижегородский союз «Белое знамя», созданный в октябре 1905 г., филиал общероссийского «Союза русского народа». «Белознаменцы» считали главной своей задачей защиту традиционных устоев русской жизни, к которым они относили семью, религию, самодержавие. Сначала «Белым знаменем» руководил купец А. А. Хохлов, затем священник Н. В. Орловский, надзиратель Владимирского реального училища С. П. Смотраков и мещанский староста К. П. Карташов. Социальную опору партии составляли городские низы - ремесленники, мастеровые, извозчики, грузчики, мелкие лавочники. Среди сторонников немало было крестьян и священников, встречались и представители интеллигенции. Пропаганду своих взглядов монархисты вели через газету «Минин».

Однако основным соперником Конституционно-демократической партии на выборах являлся умеренно-либеральный «Союз 17 октября», заслуживший в Нижнем Новгороде репутацию «купеческой партии». Нижегородское отделение партии «Союз 17 октября» было создано в начале 1906 г. В его руководящее ядро вошли: судовладелец М. И. Шипов (председатель), пароходчик Ф. В. Казанский, купцы А. А. Зайцев, И. Н. Кемарский, М. И. Будилов, управляющий пароходной конторой Н. И. Доливо-Добровольский и другие. Рупором пропаганды и агитации октябристов на время избирательной кампании стала газета «Волгарь».

В декабре 1905 г. в Нижнем Новгороде появилось местное отделение Умеренно-прогрессивной партии России. Его организаторами стали присяжные поверенные С. А. Парадизов и Д. В. Серебровский, купцы В. Н. Басов, Н. И. Волков и другие. Таким образом, нижегородским партиям практически одновременно приходилось решать и вопросы партийного строительства, и организовывать избирательную кампанию, первую в своей партийной жизни.

Среди первоочередных вопросов, которые решали партии в начале предвыборной кампании, был вопрос о принципиальном участии в 


\section{История государства и права}

DOI: 10.7256/2222-1972.2016.2.17899

выборах в условиях чрезвычайного положения и отсутствия свободы для предвыборной агитации. В начале января 1906 г. состоялось первое предвыборное собрание нижегородских кадетов, где был поднят вопрос об участии в выборах и о блоке с другими партиями. Высказывались различные мнения. Часть членов партии заявила, что не надо участвовать в избирательной кампании, поскольку права предоставлены не всем, отсутствует свобода выборов, в стране военное положение. Однако победу одержала другая точка зрения: решение отказаться от выборов было бы ошибочным, так как в Думе окажутся только правые партии. Также было принято решение выступить на выборах самостоятельно [7]. Как показали итоги кампании, решение кадетов оказалось правильным.

Вопрос об участии в предвыборной гонке в условиях чрезвычайного положения неоднократно поднимался и на собраниях нижегородских октябристов. Большинство партии считало, что в настоящее время вопрос о снятии охраны преждевременный и предлагало отнестись с доверием к правительству, которое само снимет усиленную охрану и даст свободы, когда посчитает это возможным. Тем не менее, вопрос о разрешении предвыборных собраний, считали октябристы, местные власти должны решать положительно [8]. Ответная реакция губернатора был в интересах партии: октябристы и их союзники получили право устраивать предвыборные собрания беспрепятственно. В целом лояльность партии октябристов была по достоинству оценена властью по всей России. Ей была предоставлена полная свобода деятельности и агитации, в отличие от партии кадетов. В ряде мест агитаторы от кадетской партии подвергались арестам, закрывались издания, печатавшие агитационные материалы кадетов [9].

Аналогичные с октябристами позиции на выборах занимали и члены Умеренно-прогрессивной партии. В феврале 1906 г. один из ее лидеров - С. А. Парадизов предложил партиям: Умеренно-прогрессивной, «Союзу 17 октября», правового порядка объединиться на выборах, так как программы их схожи. По его мнению, исключение составляли только кадеты, с ними объединение принципиально было невозможно. 16 февраля 1906 г. под председательством А. А. Остафьева, уездного предводителя дворянства и председателя уездной земской управы, состоялось общее собрание членов Умеренно-прогрессивной партии, на котором было принято предложение Д. В. Серебровского о коалиции с октябристами [10].

Не оставалась в стороне от избирательной кампании и церковь. 4 января 1906 г. состоялось пастырское собрание под председательством нижегородского епископа Исидора, на котором священник Н. В. Орловский призывал: «... духовенство должно принять самое деятельное участие в выборах в Думу, ...это его священная обязанность как пастырей и граждан. В Думе могут оказаться в большинстве представители крайних партий, которые объявят Думу Учредительным собранием и произойдет переворот, совершенно не соответствующий желаниям и духу русского народа». Было принято постановление о том, что духовенство должно вести агитационную работу среди прихожан по отношению к Думе и самим принять участие в выборах. Кандидатами в Думу прихожанам предложено рекомендовать членов партии «Белого знамени», а также «Союза 17 октября», Умеренно-прогрессивной партии и партии правового порядка [11]. 13 января состоялось собрание союза «Белого знамени», где, выступавшими А. А. Хохловым и Н. Н. Орловским, сформулирована одна из главных задач предвыборной кампании - противодействие революционным партиям [12]. Таким образом, решался вопрос не только о принципиальном участии в кампании, но и определялись союзники и противники в предвыборной борьбе.

В Нижегородской губернии вначале избирательная кампания протекала достаточно вяло. Газеты печатали воззвания «К избирателям», где призывали принять участие в выборах, объясняя, что «каждый голос имеет значение, каждый имеющий избирательные права должен ими воспользоваться. Нельзя уклоняться от подачи своего голоса в такое мучительно-тяжелое время, какое переживает наша родина. Дальше жить так, как мы живем, нельзя» [13]. Пресса была вынуждена констатировать совершенно неожиданное равнодушие к выборам со стороны нижегородцев. Среди причин такого отношения населения - не только отсутствие политической культуры и дремучесть российского обывателя (о чем любили потолковать либералы), но и страх, вызванный военным положением, чрезвычайной охраной, арестами и административными высылками. Кадет В. А. Ланин свидетельствовал, что простые люди боятся участвовать в какой-либо партии, что прежде чем взять какую-нибудь брошюру, обыватель спрашивает: 


\section{Исторический журнал: научные исследования № 2 (32) • 2016}

DOI: $10.7256 / 2222-1972.2016 .2 .17899$

«А что это меня ни к чему не обязывает?» И только после утвердительного ответа берет брошюру. Когда обывателю предлагается избирательный бланк, то он говорит: «Бог с ней, с этой Думой, нечего нам связываться с политикой, подальше от греха» [14].

В феврале 1906 г. газета «Волгарь» предприняла попытки проанализировать, сложившуюся в Нижнем Новгороде, ситуацию и дать прогноз о явке избирателей на выборы, который был весьма пессимистичен: «Все теперешние предвыборные партийные собрания очень малолюдны. Заявлений о желании участвовать в выборах сравнительно мало. Выборной горячки по городу нет. При выборах в городскую думу является избирателей чуть ли не только $25 \%$, что, видимо, будет и на выборах в Государственную Думу» [15]. Однако прогноз не оправдался: по итогам выборов в Нижнем Новгороде явка составила $46,6 \%$, прежде всего за счет усиления агитационной деятельности партий непосредственно накануне выборов [16]. За последние два дня перед выборами особенно активизировало свою деятельность «Белое знамя». Многие его сторонники являлись в избирательные комиссии с квитанциями об уплате членских взносов (для вступления в партию), часть приходила просто с серебряными значками партии в петлицах. Некоторые из «белознаменцев» заявляли, что лично они не стали бы участвовать в выборах, но их партия заставляет [17].

Уже в конце декабря 1905 г. в газетах появляются постоянные рубрики «К созыву Государственной Думы», «Наши партии», материал которых позволяет представить избирательные технологии политических партий начала XX в. Широко использовались традиционные методы партийной агитации - распространение брошюр, воззваний, листков. Так, нижегородские октябристы уже к середине января 1906 г. распространили среди населения 63 тыс. экземпляров брошюр «О Государственной Думе», «Сведения о порядке выборов, необходимые каждому избирателю», «К жителям», «К рабочим», «К русским людям» и т. д. В обращении «Союза 17-го октября» к крестьянам с разъяснением целей и задач Государственной Думы местный комитет партии убеждал: «Много в России накопилось бед, зла и неправды; так много, что иначе как сообща всем народом в этих бедах не разобраться. Выбирать будут все: и крестьяне, и помещики, и священнослужители, и горожане и фабричные... Крестьяне, если пожелают и будут умеючи выбирать, могут сделать так, что в Думе крестьян будет больше, чем выборных другого сословия, - все по справедливости» $[18,320]$.

Нижегородские кадеты также распространяли огромное количество партийной и агитационной литературы: программа партии, воззвания, обращения, сравнительные таблицы программ всех противоборствующих партий. Был издан агитационный материал под общим названием «Что кому дает конституционно-демократическая партия», но ориентированный на отдельные категории населения: «Всем гражданам», «Крестьянам», «Мещанам и цеховым», «Приказчикам, конторщикам и другим служащим», «Рабочим», «Кустарям и ремесленникам», «Духовенству», «Чиновникам», «Инородцам и иноверцам» [19]. Адресный характер предвыборной работы кадетов с электоратом выразился также в заключении с различными профессиональными и национально-религиозными объединениями предвыборных соглашений. В обмен на поддержку на выборах партия включала в свой кандидатский список их представителей и брала на себя обязательства отстаивать их интересы.

Эффективность таких соглашений проявилась на примере взаимовыгодного сотрудничества кадетов и нижегородской еврейской общины. Один из ее лидеров, кадет С. Г. Поляк свидетельствовал: «Мы говорили нижегородским избирателям-евреям: “Голосуйте все за Конституционно-демократическую партию. Эта партия наиболее решительно порывает со старым бюрократическим режимом, и ее обещаниям полного уравнения евреев в правах с прочим населением всего больше можно доверять". И евреи-избиратели откликнулись на этот призыв, почти все явились на выборы, все голоса подавали за партию Народной свободы и в значительной степени способствовали блестящей победе партии в городе». Аналогичное соглашение было заключено и с мусульманами, чьи духовные лидеры: ахун М. А. Сулейманов и помощник ахуна Мухамет-Фатех Соколов - вошли в кандидатский список кадетов [20, 48].

В пропаганде кадетов широко использовалась газета «Нижегородский листок», издателем которой был активный член этой партии Е. М. Ещин. На ее страницах проходила полемика между кадетами (Н. Тесленко, Е. Ещин) и представителями блока октябристов - умеренных прогрессистов (А. Остафьев, Д. Серебровский). Не было только предоставлено слово предста- 
История государства и права

DOI: $10.7256 / 2222-1972.2016 .2 .17899$

вителю «Белого знамени» Г. Добровольскому. Причем газета «Волгарь» заняла ту же позицию, отказавшись напечатать его статью [21]. Это был, скорее всего, единственный случай, когда нижегородские либералы нашли общий язык на выборах. Сторонники кадетской партии устраивали публичные лекции, ходили по квартирам, раздавая программу и брошюры. Агитационные материалы кадетов отличались доходчивостью и наглядностью, часто готовились в форме «вопрос - ответ». Кадеты сумели сформулировать удачный слоган, с которым пришли на выборы: «Мы - за народную свободу, чтобы дети нас не прокляли потом» [22].

Агитаторы противоборствующих партий отличались друг от друга своей численностью, составом, активностью, приемами. Количественно преобладали агитаторы от кадетской партии. Такая ситуация была и в Нижнем Новгороде, и в целом по стране. В массе своей - это интеллигентная молодежь, студенты, работавшие добровольно. Они активно вступали в дискуссии по всем программным вопросам партий. В день выборов (тогда агитация в день выборов не была запрещена) помогали колеблющимся избирателям определиться с выбором, объясняли, как надо складывать записку. Выяснив, за кого собирается избиратель голосовать, давали советы: «Что вы взяли! Ведь это все мракобесы. Дайте разорву. Возьмите другой бюллетень, от народной свободы». И часто избиратель бросал свой бюллетень и брал новый. А чтобы избирателя по дороге не переманили конкуренты, агитаторы-кадеты вели его до избирательной урны [23, 152].

Обладая достаточными материальными средствами, соперники кадетов в основном использовали платных агентов, которые часто честно признавались: «А нам чего? Нас наняли, мы и стоим». Часто агитаторами были работающие по приказу хозяев «молодцы» [24]. Нижегородскими октябристами за плату были приглашены рабочие из Дома Трудолюбия, которые и распространяли брошюры на заводах и фабриках, раздавали их во время крещенской ярмарки. Сами члены октябристской партии, - отмечала кадетская пресса, - считали унизительным заниматься уличной агитацией. Для кадетов это был лишний повод напомнить избирателям, что октябристы - партия «толстосумов», далеких от нужд народа.

Видимо, не очень надеясь на свои собственные силы, нижегородские октябристы пригласили в качестве «группы поддержки» выдаю- щегося адвоката Ф. Н. Плевако - члена «Союза 17 октября». Однако огромную аудиторию, собравшуюся 18 февраля 1906 г. послушать российскую знаменитость, ждало разочарование: «Монотонная, безжизненная с паузами речь, едва слышные последние слова шаблонных фраз, лишенных красоты, выразительности и силы... Плевако говорил - точно читал самую неинтересную для него книгу, которая ничем не захватывала его душу» [25]. Мнение было единое - партия больше потеряла, чем приобрела от такой «поддержки». В итоге запланированное выступление $\Phi$. Н. Плевако перед рабочими Сормовского завода было срочно отменено.

Использовались и нечестные методы ведения кампании - от использования административного ресурса и прямого подкупа избирателей до махинаций с бюллетенями. Отрицательный пример показывали, прежде всего, обе столицы, где предвыборная борьба приняла особенно ожесточенные формы. Административный ресурс использовала больше всего партия октябристов и ее союзники. Например, петербургские фабриканты и заводчики предприняли деятельную агитацию среди рабочих. А чтобы успех агитации был обеспечен, решили воспользоваться органами заводских администраций. Так, дирекция франко-русского завода, уволив предварительно часть рабочих под предлогом сокращения производства, 21 декабря1905 г. пригласила к себе мастеров различных мастерских, выбирая из них таких, которые должны оправдать доверие администрации. Она снабдила их целыми кипами «Воззваний к предстоящим выборам в Государственную Думу» для распространения по мастерским завода [26]. Служащие Обуховского завода за принадлежность к кадетской партии вообще увольнялись с завода [27].

В то время, когда остальные партии находились под особым контролем министра П. Н. Дурново, «Союзу 17 октября» была предоставлена широкая свобода агитации. Почти все петербургские фабрики и заводы были буквально завалены воззваниями, программой и обращениями от имени партии октябристов. В рабочих клубах, в трактирах, на рынках октябристы распространяли свои воззвания и вербовали сторонников. В казенных учреждениях, городской, управе, банках и т. д. всюду имелись агитаторы партии октябристов, и проводилась широкая агитационная работа [28]. В Москве служащих торгово-промышленных заведений вынуждали записываться в члены торгово-промышленной 


\section{Исторический журнал: научные исследования № 2 (32) • 2016}

DOI: 10.7256/2222-1972.2016.2.17899

партии под угрозой лишения места работы [29]. В Вятке лицам, состоящим на государственной службе, было разрешено вступать только в партию правового порядка [30]. В Костроме губернатор предложил губернскому предводителю дворянства и председателю губернской земской управы выйти из комитета кадетской партии или освободить занимаемые должности [31].

В разных местах, - с иронией пишет «Нижегородский листок», - воззвания «Союза 17 октября» распространяются ... полицией. Очевидно, полиция не в меньшей степени проникнута началами свободы, возвещенной 17 октября. И поэтому она так симпатизирует Союзу. А в ряде мест полиция заставляет крестьян записываться в монархическую партию [27]. И таких примеров вмешательства властей в ход избирательной кампании огромное множество по всей России. Только результат этого вмешательства был прямо противоположный, чего и следовало ожидать в тех исторических условиях от российского электората.

Выборы в Государственную Думу происходили не только под давлением властей, но и путем подкупа неграмотной крестьянской массы, не понимающей значения выборов. Так, в одной из волостей Нижегородской губернии выборы состоялись при следующих обстоятельствах: вся посторонняя публика, кроме станового пристава, была удалена властями из волостного правления. Перед выборами всем выборщикам было сообщено, что в случае благоприятного исхода выборов их ожидает угощение водкой, пирогом и вознаграждение в размере 10 копеек. В результате подобных выборов были избраны волостной старшина и писарь. По мере развертывания предвыборной борьбы скандальные сообщения о подкупе голосов выборщиков становились средством борьбы с соперниками. Например, избранный (от губернии) в Государственную Думу В. П. Филатов, сделал заявление о том, что некоторые лица приглашали выборщиков-крестьян в трактир Афанасьева, бесплатно угощали вином, водкой, закусками, уговаривая класть шары за Н. А. Бугрова (беспартийного либерала, близкого к октябристам) и А. А. Остафьева (кандидата от правой Умеренно-прогрессивной партии). Раздавали пакеты с надписями, что надо выбирать именно этих кандидатов. Остафьев пытался оправдаться, объясняя, что «угощение выразилось только в чае», что «агитация имеет разные формы». В ответ кадеты угрожали подать на него в суд [32].
Своеобразной формой подкупа был и подвоз избирателей на избирательные участки. Например, в день выборов в Москве кадетами были наняты специальные лихачи, подвозившие избирателей к помещению избирательной комиссии. «Партийные» извозчики снабжены были яркими зелеными лентами с надписью: «Партия народной свободы». Партии в погоне за голосами не брезговали никакими средствами. Скандальные стычки между кадетами и октябристами особого накала достигли в столицах - уничтожение агитационных материалов соперников, передергивания, ложные обвинения приводили чуть ли не к банальным потасовкам. Так, один из агитаторов - октябристов, критикуя программу кадетов, заявил, что вся кадетская партия состоит из революционеров, что тайное желание кадетов - ввести в России республику и раздать окраины России инородцам. Даже А. И. Гучков и тот заявил, что кадеты И. И. Петрункевич, $\Phi$. И. Родичев и другие в одном из городов России присутствовали на собраниях революционеров. Присутствовавшие на собрании кадеты потребовали от А. И. Гучкова объяснений по поводу столь тяжкого обвинения. Поднялся невообразимый шум, назревала потасовка, до драки дело не дошло - собрание быстро закрыли [33].

В Москве в день выборов агитаторы кадетской партии на улицах раздавали «Русские ведомости» и «Путь». Сразу же были обнаружены попытки соперничавших партий скупать «Русские Ведомости» и уничтожать их. В Петербурге октябристы, не сумев разбить кадетов по программным вопросам, перешли на личности. Рекорд побило «Новое время» А. С. Суворина, которое копалось в интимных сторонах жизни кандидатов от кадетской партии, «цеплялось» за их генеалогию, называя кандидатами «от Израилева населения столицы» [34]. Союз «Белого знамени» выпустил 11 воззваний, направленных лично против кадетов [35].

По мере развертывания кампании ситуация накалялась. Большой общественный резонанс вызвал скандал с бюллетенями. Так, нижегородский комитет кадетской партии в той же самой типографии, где печатались бюллетени городской управой для предстоящих выборов, напечатал такие же избирательные бюллетени для своих целей. В эти бюллетени комитет вписал кандидатов от кадетской партии, заполнив их фамилиями полностью. Таким образом, получились готовые для подачи бюллетени. Эти бюллетени в именных конвертах разносились 


\section{История государства и права}

DOI: $10.7256 / 2222-1972.2016 .2 .17899$

не только членам партии, но и внепартийным избирателям с сопроводительным письмом, где призывалось голосовать всем списком за партию кадетов. Это было расценено как давление на избирателей, но, вслед за кадетами, аналогичные готовые бюллетени напечатали и октябристы, и «белознаменцы» [36].

Отмечались случаи хищения избирательных списков. В результате 19 февраля 1906 г. министр внутренних дел П. Н. Дурново разослал циркуляр всем губернаторам и начальникам всех губернских жандармских управлений по усилению мер охраны учреждений, в которых выставляются эти списки [37].

Реакция на подобные методы ведения избирательной кампании политическими партиями, недоверие к ним в целом со стороны рабочего и крестьянского населения были адекватными - от неучастия в избирательном процессе до прямого издевательства над ним. Крестьян волновали не партийные предвыборные интриги, а как выбрать человека, который будет отстаивать их интересы. Аргументация была ими выстрадана: «Мы выбирать не умеем: выберем вот от землевладельцев, которые не менее 250 десятин имеют, а какие они будут соболезнователи крестьянам? Выбираем мы гласных в земскую управу, будто люди для крестьянства реальные, а смотришь, мало погодя, рощу купил и живет помещиком» [38].

Газета «Наша жизнь» рассказывает о фактах саботажа выборов рабочими Невской заставы: на Спасской фабрике из-за отказа рабочих выборы не состоялись. На фабрике Макса Велера и на Петровской фабрике рабочие заявили, что будут выбирать только по рекомендации Совета рабочих депутатов и потребовали освобождения членов этого Совета из-под ареста. На вагонном заводе выбрали глухонемого, но и тот отказался. На Александровском заводе выбрали дымовую заводскую трубу, потому что такому депутату обеспечена неприкосновенность. На заводе Паля выбрали собаку Розку, дабы не обременять стесненные финансы правительства 10-рублевым содержанием депутата, так как ее можно содержать и на 15 копеек в день [39]. Свое отношение к выборам избиратели демонстрировали и в ходе голосования: вместо фамилий писали слово «бойкот», сдавали чистые бланки, в сатирической форме переиначивали фамилии кандидатов, называли Думу «кукольной», «игрушечной», требовали созыва Учредительного собрания, просто не являлись на выборы и т. д. [40].
Подсчет голосов еще не закончился, а по Нижнему Новгороду поползли слухи, будто бы выборы кассированы, будто бы от министра последовал приказ губернатору и выборы отменены. Особенно активно искали поводы к кассации выборов представители «Белого знамени», крайне недовольные победой кадетов. В губернскую избирательную комиссию стали поступать протесты с требованием отменить выборы по всем четырем избирательным участкам Нижнего Новгорода. Часть жалоб была основана на фактах нарушения инструкции министра внутренних дел о выборах от 24 февраля 1906 г. По инструкции бланки избирательных записок должны заблаговременно рассылаться городскими и земскими управами избирателям, проживающим в городах, при особых именных объявлениях о времени и месте выборов. Это требование было нарушено и часть избирателей должны были узнавать эту информацию из газет, а многие газет не получали и не читали. Огромное число избирателей не знали, что необходимо идти самим за бланком избирательной записки и объявлением. Этим воспользовались партийные комитеты и разослали бюллетени с напечатанными именами будущих выборщиков. А по закону в избирательную записку имена выборщиков должны быть вписаны лично самим избирателем. Таким образом, было нарушено требование тайного голосования.

Вторая часть жалоб также была основана на нарушении той же инструкции. Поскольку предварительной рассылки избирательных записок и именных объявлений о месте и времени выборов не было, то на выборы к избирательным урнам явилось только 4592 человек из 9844 избирателей. Кроме этого, многочисленные жалобы поступили в министерство внутренних дел на то, что в избирательные списки внесено много лиц, давно уже умерших и не внесены многие крестьяне, участие которых в выборах являлось нежелательным для администрации. Были крестьянские жалобы на то, что полиция стесняла свободу выборов, что население не было оповещено о дне выборов, поэтому, например, в Горбатовском уезде Нижегородской губернии на съезд из 1400 владельцев-крестьян явилось всего 10 человек [41]. Однако губернская комиссия жалобы оставила без рассмотрения, и результаты выборов были признаны действительными.

Выборы членов Государственной Думы от Нижегородской губернии проходили 14-16 апреля 1906 г. Всего было выбрано 6 человек: три 


\section{Исторический журнал: научные исследования № 2 (32) • 2016}

DOI: $10.7256 / 2222-1972.2016 .2 .17899$

человека из беспартийных и по одному из членов Конституционно-демократической, Умеренно-прогрессивной и партии правового порядка. Выборы показали, что в губернии ведущие партии не успели или не смогли провести действенную агитационную кампанию среди населения.

В Нижнем Новгороде, где партийная пропаганда и агитация велись достаточно активно, лидировали кадеты. От Нижнего Новгорода избрано 80 выборщиков, из них 79 человек - из кандидатов кадетской партии. Поэтому исход выборов 19 марта 1906 г. был предрешен. Членом Государственной Думы стал кадет А. А. Савельев - председатель губернской управы, юрист по образованию, публицист и видный земский деятель [42]. Впоследствии избирался депутатом и второй, и третьей Думы. Таким образом, в Нижнем Новгороде кадетская партия одержала убедительную победу. Определенную роль в этом сыграли и ее предвыборная партийная агитация, личные качества кадетов-нижегородцев, участвовавших в ней, более привлекательная для основной массы населения программа, разнообразие форм работы с электоратом, неучастие в выборах партий эсеров и социал-демократов, ошибки соперников, преследование властей.
Однако более глубокая причина такого исхода выборной кампании заключалась в наличии в России огромной массы протестного электората. Поэтому трудно не согласиться с лидером октябристов А. И. Гучковым, пытавшимся честно разобраться в причинах поражения своей партии на выборах. Его вывод был следующим: «Основная причина успехов конституционно-демократической партии кроется в страстном желании русского обывателя, призванного к урне, выразить протест против ненавистного ему режима, против не знающей границ реакции, против всей системы внутренней политики последнего времени, озлобившей всех и вся. Естественно, что масса избирателей поддержала партию наиболее оппозиционную, наиболее преследуемую, ...победа кадетов создана политикой министерства Витте - Дурново» [43].

Вывод видного политика начала XX в., опыт первого российского парламента, вся история дореволюционного парламентаризма не потеряли актуальности и для начала XXI в. Общество без конструктивных партнерских взаимоотношений между народом, законодательной и исполнительной властями - общество без будущего.

\section{Библиография:}

1. История России. XX век. Учебное пособие для студентов. / Под ред. В. П. Дмитренко. М.: АСТ, 1996. 607 с.

2. Политическая история: Россия - СССР - Российская Федерация. В 2 т. Т.І. / Под ред. С. В. Кулешова. М.: ТЕРРА, 1996. 656 с.

3. Марченко М. А. Краткий обзор документов и литературы ГУ ГОПАНО по выборам в I Государственную Думу. // Материалы Международной научно-практической конференции «Сто лет российского парламентаризма: история и современность», 7 апреля 2006 г. / Под ред. Г. В. Набатова. Нижний Новгород: Издательство Нижегородского госуниверситета, 2006. С. 418-422.

4. Нижегородский листок. - 1906. - 30 января.

5. Нижегородский листок. - 1906. - 2 февраля.

6. Нижегородский листок. - 1905. - 18 декабря.

7. Нижегородский листок. - 1906. - 8, 26 января.

8. Волгарь. $-1906 .-16$ января.

9. Нижегородский листок. - 1906. - 26, 28 января; 4, 22 февраля.

10. Волгарь. - 1906. - 6, 17 февраля.

11. Волгарь. $-1906 .-7$ января.

12. Нижегородский листок. - 1906. - 15 января.

13. Нижегородский листок. - 1905. - 22 декабря.

14. Волгарь. - 1906. - 22 января.

15. Волгарь. - 1906. -21 февраля.

16. Волгарь. - 1906. - 25 марта.

17. Волгарь. - 1906. - 16 марта.

18. Обращение «Союза 17-го Октября» к крестьянам с разъяснением целей и задач Государственной думы. // Общественно-политические процессы, партии и движения в Нижегородской губернии в конце XIX-начале XX вв. Учебное пособие в 2 томах. Том II. / Под ред. Г. В. Набатова. Нижний Новгород: Издательство Нижегородского госуниверситета, 2001. C.320-324.

19. Нижегородский листок. - 1906. - 12 марта.

20. Селезнев Ф. А. История выборов в России с древнейших времен до конца ХХ в. (на примере Нижегородского края). Учебное пособие. Нижний Новгород: Издательство Нижегородского госуниверситета, 2012. 104 с.

21. Нижегородский листок. - 1906. - 15,16,18 марта. 
22. Нижегородский листок. - 1906. - 29 марта.

23. Медведева Т. А. Из опыта ведения политическими партиями предвыборной кампании в I Государственную Думу. // Материалы Международной научно-практической конференции «Сто лет российского парламентаризма: история и современность», 7 апреля 2006 г. / Под ред. Г. В. Набатова. Нижний Новгород: Издательство Нижегородского госуниверситета, 2006. С. 148-155.

24. Волгарь. - 1906. - 20, 28, 29, 30 марта.

25. Волгарь. - 1906. - 20 февраля.

26. Нижегородский листок. - 1905. - 28 декабря.

27. Нижегородский листок. - 1906. - 5 февраля.

28. Нижегородский листок. - 1906. - 1 января.

29. Нижегородский листок. - 1906. - 11 января.

30. Нижегородский листок. - 1906. - 28 января.

31. Нижегородский листок. - 1906. - 21 февраля.

32. Нижегородская газета. - 1906. - 19 апреля.

33. Нижегородский листок. - 1906. - 21 марта.

34. Волгарь. - 1906. - 27, 28 марта.

35. Листок Нижегородской группы Партии Народной Свободы. - 1906. - 16 апреля.

36. Волгарь. - 1906. - 18 марта.

37. Нижегородский листок. - 1906. - 23 февраля.

38. Волгарь. - 1906. - 5 марта.

39. Нижегородский листок. - 1906. - 13 марта.

40. Волгарь. - 1906. - 21 марта.

41. Нижегородский листок. - 1906. - 1,11 апреля.

42. Волгарь. - 1906. - 1, 18 апреля.

43. Волгарь. - 1906. - 31 марта.

44. Общественно-политические процессы, партии и движения в Нижегородской губернии в конце XIX-начале XX вв. Учебное пособие в 2 томах. Том I. /Под ред. Г. В. Набатова. Нижний Новгород: Издательство Нижегородского госуниверситета, 2001. 262 с.

45. Общественно-политические процессы, партии и движения в Нижегородской губернии в конце XIX-начале XX вв. Учебное пособие в 2 томах. Том II. /Под ред. Г. В. Набатова. Нижний Новгород: Издательство Нижегородского госуниверситета, 2001.366 с.

46. Политические партии России. Конец XIX-первая треть XX века. Энциклопедия. М.: РОССПЭН, 1996. 872 с.

47. Селезнев Ф. А. Конституционные демократы и буржуазия (1905-1917). Нижний Новгород: Издательство Нижегородского госуниверситета, 2006. $228 \mathrm{c}$.

48. Таврические чтения 2013. Актуальные проблемы парламентаризма: история и современность. Международная научная конференция, Санкт-Петербург, Таврический дворец, 1-12 декабря 2013 г. Сборник научных статей. В 2-х частях. Ч. 1. / Под ред. А. Б. Николаева. СПб.: ЭлекСис, 2014. 360 с.

49. Таврические чтения 2013. Актуальные проблемы парламентаризма: история и современность. Международная научная конференция, Санкт-Петербург, Таврический дворец, 1-12 декабря 2013 г. Сборник научных статей. В 2-х частях. Ч. 2. / Под ред. А. Б. Николаева. СПб.: ЭлекСис, 2014. 180 с.

50. Селунская Н.Б. Механизм формирования политических представлений выборщиков в России в начале XX в. // Социодинамика. - 2013. - 5. - С. 190 - 220. DOI: 10.7256/2409-7144.2013.5.654. URL: http://www.e-notabene.ru/pr/article_654.html

51. Мовсесян М. Выборы в Государственную Думу РФ как фактор становления и развития политической системы в современной России // Международные отношения. - 2014. - 4. - С. 530 - 539. DOI: 10.7256/2305-560X.2014.4.13179.

\section{References (transliterated):}

1. Istoriya Rossii. KhKh vek. Uchebnoe posobie dlya studentov. / Pod red. V. P. Dmitrenko. M.: AST, 1996. 607 s.

2. Politicheskaya istoriya: Rossiya - SSSR - Rossiiskaya Federatsiya. V 2 t. T.I. / Pod red. S. V. Kuleshova. M.: TERRA, 1996. 656 s.

3. Marchenko M. A. Kratkii obzor dokumentov i literatury GU GOPANO po vyboram v I Gosudarstvennuyu Dumu. // Materialy Mezhdunarodnoi nauchno-prakticheskoi konferentsii «Sto let rossiiskogo parlamentarizma: istoriya i sovremennost'», 7 aprelya 2006 g. / Pod red. G. V. Nabatova. Nizhnii Novgorod: Izdatel'stvo Nizhegorodskogo gosuniversiteta, 2006. S. 418-422.

4. Nizhegorodskii listok. - 1906. -30 yanvarya.

5. Nizhegorodskii listok. $-1906 .-2$ fevralya.

6. Nizhegorodskii listok. - 1905. -18 dekabrya.

7. Nizhegorodskii listok. - 1906. - 8, 26 yanvarya.

8. Volgar'. -1906. -16 yanvarya.

9. Nizhegorodskii listok. - 1906. - 26, 28 yanvarya; 4, 22 fevralya.

10. Volgar'. - 1906. $-6,17$ fevralya.

11. Volgar'. $-1906 .-7$ yanvarya.

12. Nizhegorodskii listok. - 1906. - 15 yanvarya.

13. Nizhegorodskii listok. - 1905. - 22 dekabrya.

14. Volgar'. - 1906. - 22 yanvarya. 


\section{Исторический журнал: научные исследования № 2 (32) • 2016}

DOI: $10.7256 / 2222-1972.2016 .2 .17899$

15. Volgar'. - 1906. - 21 fevralya.

16. Volgar'. - 1906. - 25 marta.

17. Volgar'. - 1906. - 16 marta.

18. Obrashchenie «Soyuza 17-go Oktyabrya» k krest'yanam s raz"yasneniem tselei i zadach Gosudarstvennoi dumy. // Obshchestvenno-politicheskie protsessy, partii i dvizheniya v Nizhegorodskoi gubernii v kontse XIX-nachale XX vv. Uchebnoe posobie v 2 tomakh. Tom II. / Pod red. G. V. Nabatova. Nizhnii Novgorod: Izdatel'stvo Nizhegorodskogo gosuniversiteta, 2001. S.320-324.

19. Nizhegorodskii listok. - 1906. - 12 marta.

20. Seleznev F. A. Istoriya vyborov v Rossii s drevneishikh vremen do kontsa KhKh v. (na primere Nizhegorodskogo kraya). Uchebnoe posobie. Nizhnii Novgorod: Izdatel'stvo Nizhegorodskogo gosuniversiteta, 2012. $104 \mathrm{~s}$.

21. Nizhegorodskii listok. - 1906. - 15,16,18 marta.

22. Nizhegorodskii listok. - 1906. - 29 marta.

23. Medvedeva T. A. Iz opyta vedeniya politicheskimi partiyami predvybornoi kampanii v I Gosudarstvennuyu Dumu. // Materialy Mezhdunarodnoi nauchno-prakticheskoi konferentsii «Sto let rossiiskogo parlamentarizma: istoriya i sovremennost'», 7 aprelya 2006 g. / Pod red. G. V. Nabatova. Nizhnii Novgorod: Izdatel'stvo Nizhegorodskogo gosuniversiteta, 2006. S. 148-155.

24. Volgar'. - 1906. - 20, 28, 29, 30 marta.

25. Volgar'. - 1906. - 20 fevralya.

26. Nizhegorodskii listok. - 1905. - 28 dekabrya.

27. Nizhegorodskii listok. -1906 . -5 fevralya.

28. Nizhegorodskii listok. - 1906. - 1 yanvarya.

29. Nizhegorodskii listok. - 1906. - 11 yanvarya.

30. Nizhegorodskii listok. - 1906. - 28 yanvarya.

31. Nizhegorodskii listok. - 1906. - 21 fevralya.

32. Nizhegorodskaya gazeta. $-1906 .-19$ aprelya.

33. Nizhegorodskii listok. - 1906. - 21 marta.

34. Volgar'. - 1906. - 27, 28 marta.

35. Listok Nizhegorodskoi gruppy Partii Narodnoi Svobody. - 1906. - 16 aprelya.

36. Volgar'. - 1906. - 18 marta.

37. Nizhegorodskii listok. - 1906. - 23 fevralya.

38. Volgar'. - 1906. - 5 marta.

39. Nizhegorodskii listok. - 1906. - 13 marta.

40. Volgar'. - 1906. - 21 marta.

41. Nizhegorodskii listok. - 1906. - 1,11 aprelya.

42. Volgar'. - 1906. - 1, 18 aprelya.

43. Volgar'. - 1906. - 31 marta.

44. Obshchestvenno-politicheskie protsessy, partii i dvizheniya v Nizhegorodskoi gubernii v kontse XIX-nachale XX vv. Uchebnoe posobie v 2 tomakh. Tom I. /Pod red. G. V. Nabatova. Nizhnii Novgorod: Izdatel'stvo Nizhegorodskogo gosuniversiteta, 2001. $262 \mathrm{~s}$.

45. Obshchestvenno-politicheskie protsessy, partii i dvizheniya v Nizhegorodskoi gubernii v kontse XIX-nachale XX vv. Uchebnoe posobie v 2 tomakh. Tom II. /Pod red. G. V. Nabatova. Nizhnii Novgorod: Izdatel'stvo Nizhegorodskogo gosuniversiteta, 2001. $366 \mathrm{~s}$.

46. Politicheskie partii Rossii. Konets XIX-pervaya tret' XX veka. Entsiklopediya. M.: ROSSPEN, 1996. $872 \mathrm{~s}$.

47. Seleznev F. A. Konstitutsionnye demokraty i burzhuaziya (1905-1917). Nizhnii Novgorod: Izdatel'stvo Nizhegorodskogo gosuniversiteta, 2006. $228 \mathrm{~s}$.

48. Tavricheskie chteniya 2013. Aktual'nye problemy parlamentarizma: istoriya i sovremennost'. Mezhdunarodnaya nauchnaya konferentsiya, Sankt-Peterburg, Tavricheskii dvorets, 1-12 dekabrya 2013 g. Sbornik nauchnykh statei. V 2-kh chastyakh. Ch. 1. / Pod red. A. B. Nikolaeva. SPb.: ElekSis, 2014. 360 s.

49. Tavricheskie chteniya 2013. Aktual'nye problemy parlamentarizma: istoriya i sovremennost'. Mezhdunarodnaya nauchnaya konferentsiya, Sankt-Peterburg, Tavricheskii dvorets, 1-12 dekabrya 2013 g. Sbornik nauchnykh statei. V 2-kh chastyakh. Ch. 2. / Pod red. A. B. Nikolaeva. SPb.: ElekSis, 2014. $180 \mathrm{~s}$.

50. Selunskaya N.B. Mekhanizm formirovaniya politicheskikh predstavlenii vyborshchikov v Rossii v nachale KhKh v. // Sotsiodinamika. - 2013. - 5. - C. 190 - 220. DOI: 10.7256/2409-7144.2013.5.654. URL: http://www.e-notabene.ru/pr/ article_654.html

51. Movsesyan M. Vybory v Gosudarstvennuyu Dumu RF kak faktor stanovleniya i razvitiya politicheskoi sistemy v sovremennoi Rossii // Mezhdunarodnye otnosheniya. - 2014. - 4. - C. 530 - 539. DOI: 10.7256/2305-560X.2014.4.13179. 